Western University

Scholarship@Western

$1-2019$

Twinkle-Associated Mitochondrial DNA Depletion.

Salma Remtulla

Cam-Tu Emilie Nguyen

Chitra Prasad

Craig Campbell

Follow this and additional works at: https://ir.lib.uwo.ca/paedpub

Part of the Pediatrics Commons 
Clinical Observations

\title{
Twinkle-Associated Mitochondrial DNA Depletion
}

\author{
Salma Remtulla, MD, FRCPC ${ }^{\text {, }}$ Cam-Tu Emilie Nguyen, MD, FRCPC ${ }^{\mathrm{b}}$, \\ Chitra Prasad, MD, FRCPC, FCCMG ${ }^{c}$, Craig Campbell, MD, MSc, FRCPC ${ }^{\mathrm{c}, *}$ \\ a Division of Children's Health, Trillium Health Partners, Mississauga, Ontario, Canada \\ ${ }^{\mathrm{b}}$ Neurosciences Department Université de Montréal, Montréal, QC, Canada \\ ${ }^{\mathrm{c}}$ Department of Paediatrics, Children's Health Research Institute, Western University, London, Ontario, Canada
}

\section{ARTICLE INFO}

Article history:

Received 12 February 2018

Accepted 4 August 2018

\section{Keywords:}

TWINKLE

PEO1

C10orf2

mtDNA

Encephalopathy

Liver

Hepatocerebral syndrome

Mitochondrial DNA depletion

syndrome

\begin{abstract}
BACKGROUND: Autosomal recessive mutations in the nuclear Twinkle (C10orf2) gene cause a mitochondrial DNA depletion syndrome (MDS) characterized by early onset hepatoencephalopathy.

METHODS: We report a severe, early onset encephalopathy and multisystem failure case caused by novel recessive Twinkle gene mutations. Patient clinical, laboratory, and pathological features are reported and Twinkle-associated MDS literature reviewed.

RESULTS: Typical presentation includes symptom onset before age six months, failure to thrive, psychomotor regression, epileptic encephalopathy, sensory axonal neuropathy, cholestatic liver dysfunction, and occasionally, renal tubulopathy, movement disorders, and ophthalmoplegia. Death is typical before age four years.

CONCLUSIONS: In the differential diagnosis of early onset encephalopathy and multisystem failure, MDS should be considered.
\end{abstract}

(C) 2018 Elsevier Inc. All rights reserved.

\section{Introduction}

Mitochondrial depletion syndromes (MDS) are comprised of autosomal recessive disorders caused by mutations in nuclear genes encoding for key enzymes involved in mitochondrial DNA (mtDNA) replication and/ or maintenance. These mutations result in decreased mtDNA copy number, leading to impaired energy production in various tissues.

The C10orf2 gene, also called PEO1 or Twinkle, encodes the mtDNA replicative Twinkle helicase-important for mtDNA replication. Dominant mutations in the Twinkle gene can cause multiple mtDNA deletions and result in chronic progressive external ophthalmoplegia or

\footnotetext{
Declarations of interest: None.

* Communications should be addressed to: Dr. Craig Campbell, Department of Paediatrics, Children's Health Research Institute, Western University, B1-177, Victoria campus, LHSC, 800 Commissioners Rd. E, London, ON N6A2W7, Canada.

E-mail address: Craig.campbell@lhsc.on.ca
}

mitochondrial myopathy. Recessive Twinkle mutations cause mtDNA depletion.

MDS are phenotypically heterogeneous and manifest clinically as early onset encephalopathy, hepatoencephalopathy, encephalomyopathy, infantile onset spinocerebellar ataxia, or Perrault syndrome., ${ }^{2,3}$ The hepatocerebral form of MDS is associated with mutations in Twinkle, POLG1, DGUOK, and MPV17. MDS associated with POLG1 is known as Alpers-Huttenlocher (Alpers) syndrome.

We describe a child with severe, early onset encephalopathy and multisystem failure caused by recessive Twinkle gene mutations that have never been documented before. We also review the literature on Twinkleassociated MDS.

\section{Patient description}

This girl was born vaginally at $38+5$ weeks gestation to a 32-year-old G4P3 mother, on venlafaxine and bupropion throughout pregnancy, and a healthy 33-year-old father. The parents are Caucasian and non-consanguineous. 
There were four healthy siblings. Intrauterine growth restriction was noted at 32 weeks gestation. Birth weight was $2.63 \mathrm{~kg}$ (5th percentile). She had poor oromotor coordination from birth, requiring gastrostomy tube feeding by age four months.

At two months of age, weight, length, and head circumference were all less than the third percentile. Examination of extraocular movements was suggestive of internuclear ophthalmoplegia. Visual fixation was inconsistent. Severe hypotonia with significant head lag was present. Deep tendon reflexes were absent. Episodes of nonepileptic choreiform tongue movements were observed. A prolonged generalized seizure occurred in the context of hyponatremia (Na $117 \mathrm{mmol} / \mathrm{L}$ ).

Initial laboratory investigations at age two months revealed a mild raised anion gap metabolic acidosis. By age three months, serum lactate was mildly elevated to $5 \mathrm{mmol} / \mathrm{L}$ (normal < 2.8). Urine amino acids revealed a generalized aminoaciduria. Plasma amino acids, ammonia, urine organic acids, plasma acylcarnitine profile, transferrin isoelectric focusing, and very long chain fatty acids were normal. Creatine kinase was normal. Initial liver function testing revealed mild elevations in alanine aminotransferase (ALT) $46 \mathrm{U} / \mathrm{L}$ (normal $\leq 33$ ), aspartate aminotransferase (AST) $61 \mathrm{U} / \mathrm{L}$ (normal $\leq 32$ ), gamma-glutamyltransferase (GGT) $467 \mathrm{U} / \mathrm{L}$ (normal $\leq 204$ ), and lactate dehydrogenase $535 \mathrm{U} / \mathrm{L}$ (normal $<300)$. Serum alpha-fetoprotein level was elevated at age 3.5 months (488 ug/L; normal $\leq 5$ ).

The presence of proteinuria, elevated urine/microalbumin/creatinine ratio $(167 \mathrm{mg} / \mathrm{mmol}$ creatinine; normal 0 to 2.8), elevated urine $\mathrm{pH}(>9.0)$, and ongoing need for oral sodium and bicarbonate supplementation were suggestive of a tubular nephropathy.

Abdominal ultrasound revealed mild splenomegaly, and chest X-ray showed thymic hypoplasia. Echocardiogram, electrocardiogram, brain magnetic resonance imaging (MRI) were normal initially. Nerve conduction studies (motor: tibial and peroneal, sensory; median, radial, ulnar, superficial peroneal, and sural) showed absent sensory responses and normal motor responses. Repetitive nerve stimulation was normal. Needle electromyography showed myopathic units. Electroencephalogram revealed bilateral, independent temporal interictal epileptiform discharges.

By age four months, she developed stridor requiring supraglottoplasty for laryngomalacia; hypertension, treated with amlodipine; bilateral asymmetric ptosis, not responsive to pyridostigmine trial; and refractory status epilepticus requiring pentobarbital infusion. She developed severe lactic acidosis, refractory to sodium bicarbonate boluses. On the last day of life, serum lactate was persistently elevated above $15 \mathrm{mmol} / \mathrm{L}$. Cerebrospinal fluid (CSF) revealed elevated lactate $45 \mathrm{mmol} / \mathrm{L}$ (normal $0.62-2.10$ ), pyruvate $0.25 \mathrm{mmol} / \mathrm{L}$ (normal 0.06-0.22), and lactate/pyruvate ratio 182 (normal 10-25). A mild increase in concentration of most amino acids was noted in the CSF, which can be secondarily increased in all conditions with lactic acidosis and hyperammonemia. Liver function testing revealed marked elevations in ALT $209 \mathrm{U} / \mathrm{L}$, AST $306 \mathrm{U} / \mathrm{L}$, ALP $605 \mathrm{U} / \mathrm{L}$ (normal < 449), GGT $874 \mathrm{U} / \mathrm{L}$, ammonia $90 \mathrm{umol} / \mathrm{L}$ (normal 11-48), and INR 3.4 (normal 0.9-1.1), as well as low Klaus Fibrinogen $0.85 \mathrm{~g} / \mathrm{L}$ (normal 2-4) and albumin $19 \mathrm{~g} / \mathrm{L}$ (normal 38-54). Repeat brain MRI at four months demonstrated interval development of mild cerebral atrophy. MR spectroscopy was normal. Following discussion with family, care was withdrawn and the patient passed away at age four months.

Autopsy revealed severe microvesicular steatosis of the liver tissue with ascites and bilateral pulmonary edema. Muscle histology demonstrated type 1 fiber predominance, with significant size variability in the muscle fibers and increases in sarcoplasmic lipid droplets and internal nuclei. Electron microscopy showed structurally abnormal mitochondria, with marked vacuolation, disarray of the cristae, and a close association between abnormal mitochondria and the lipid droplets. There was slight evidence of fiber necrosis and inflammatory infiltrate. Ragged red and blue fibers were not evident through Gomori trichrome staining and NADH-TR, respectively. There were a few scattered cox-negative fibers. Numerous fibers indicated an increase in oil red 0 staining. Respiratory chain enzyme studies revealed decreased activity of all mitochondrial respiratory chain complexes. Central nervous system neuropathological examination revealed widespread "metabolic" encephalopathic changes, characterized by neuronal loss, secondary gliosis, focal mineralization of thalamic neurons, and astrocytic changes reminiscent of Alzheimer type II cells.

Chromosomal microarray was performed initially with normal results. Subsequently, a comprehensive next generation sequencing panel of 183 genes associated with muscular dystrophy and myopathy revealed two heterozygous novel variants in the C10orf2 gene. The first variant, c.853C $>\mathrm{T}$, was reportedly the type expected to be pathogenic and results in change of an arginine residue to a stop codon at amino acid position 285 (p.Arg285Ter), predicted to cause premature truncation of the protein. The second variant, $c 1592+4 A>G$ is an intronic splice site variant, resulting in change from an adenine to a guanine residue located at c. $1592+4$ and was predicted to alter the exon 3 donor site with potential to alter splicing. The data were insufficient for definitive classification and the variant classified as of unknown significance. Sanger sequencing confirmed the results. Parental testing revealed the p.R285* variant was paternally and the c. $1592+4 A>G$ variant maternally inherited.

\section{Discussion}

We describe the clinical, laboratory, pathologic and molecular features of a patient with two novel heterozygous mutations in the Twinkle gene, presenting with early onset encephalopathy, status epilepticus, and liver failure, resulting in death at age four months.

Only ten patients have been previously reported with MDS caused by autosomal recessive Twinkle mutations, with survival ranging from three months to 4.5 years (Table). ${ }^{4-8}$

Commonly reported clinical features of failure to thrive, severe hypotonia, seizures, and abnormal eye movements were represented in our patient. Dyskine$\operatorname{sias}^{5,8}$ and ataxia ${ }^{5}$ have been reported in a subset of patients. These features presented after a variable period of normal psychomotor development, with symptom onset before age six months in all reported patients. Until 
Table.

Comparison of Clinical Features in Patient with Twinkle-Associated Mitochondrial DNA Depletion Syndrome

\begin{tabular}{|c|c|c|c|c|c|c|c|c|}
\hline Case & Symptom Onset & Survival & Neurological Features & $\begin{array}{l}\text { Non-Neurological } \\
\text { Features }\end{array}$ & MRI Brain & Electrophysiology & Mutation(s) & Ref \\
\hline 1 & Neonatal & 3 years & $\begin{array}{l}\text { Neonatal: Axial hypotonia/ } \\
\text { peripheral hypertonia, } \\
\text { developmental delay, } \\
\text { muscle atrophy (with ele- } \\
\text { vated CK) } \\
10 \text { months: seizures, } \\
\text { areflexia }\end{array}$ & $\begin{array}{l}\text { Neonatal: mild hepatic } \\
\text { dysfunction, lactic } \\
\text { acidosis. }\end{array}$ & $\begin{array}{l}6 \text { months: subdural col- } \\
\text { lection, mild ventricu- } \\
\text { lar dilatation }\end{array}$ & $\mathrm{N} / \mathrm{A}$ & $\begin{array}{l}\text { Homozygous c. } 1370 \mathrm{C}>\mathrm{T} \\
\text { (p.Thr457Ile) } \\
\text { (first cousin of cases } 2 \\
\text { and 3) }\end{array}$ & [3] \\
\hline 2 & Not reported & 2 years & $\begin{array}{l}\text { Axial hypotonia, seizures, } \\
\text { peripheral sensory neu- } \\
\text { ropathy, abnormal eye } \\
\text { movements. }\end{array}$ & $\begin{array}{l}\text { Failure to thrive, mild } \\
\text { liver insufficiency, ele- } \\
\text { vated lactate. }\end{array}$ & $\mathrm{N} / \mathrm{A}$ & $\mathrm{N} / \mathrm{A}$ & $\begin{array}{l}\text { Homozygous c.1370C }>\mathrm{T} \\
\text { (p.Thr457Ile) } \\
\text { (sibling of case } 3 \text { ) }\end{array}$ & [3] \\
\hline 3 & Not reported & 2 years & $\begin{array}{l}\text { Axial hypotonia, seizures, } \\
\text { peripheral sensory neu- } \\
\text { ropathy, abnormal eye } \\
\text { movements. }\end{array}$ & $\begin{array}{l}\text { Failure to thrive, mild } \\
\text { liver insufficiency, ele- } \\
\text { vated lactate. }\end{array}$ & $\mathrm{N} / \mathrm{A}$ & $\mathrm{N} / \mathrm{A}$ & $\begin{array}{l}\text { Homozygous c.1370C }>\text { T } \\
\text { (p.Thrus7lle) } \\
\text { (sibling of case 2) }\end{array}$ & [3] \\
\hline 4 & 6 months & 4.5 years & $\begin{array}{l}6 \text { months: Abnormal eye } \\
\text { movements, } \\
8 \text { months: Hypotonia, } \\
\text { psychomotor regression } \\
13 \text { months: Poor visual } \\
\text { fixation, ophthalmopare- } \\
\text { sis, areflexia } \\
18 \text { months: Hearing } \\
\text { impairment } \\
3.5 \text { years: Ataxia, distal } \\
\text { amyotrophy, extensor } \\
\text { plantar responses } \\
4.5 \text { years: Epilepsia parti- } \\
\text { alis continua progressing } \\
\text { to status epilepticus }\end{array}$ & $\begin{array}{l}8 \text { months: Feeding intol- } \\
\text { erance } \\
12 \text { months: Hepatic } \\
\text { dysfunction (transami- } \\
\text { nitis, elevated AFP and } \\
\text { LD), elevated lactate. }\end{array}$ & $\begin{array}{l}3.5 \text { years: T2-hyperin- } \\
\text { tensities around } 4 \text { th } \\
\text { ventricle, superior cer- } \\
\text { ebellar peduncle, and } \\
\text { dentate nuclei; cere- } \\
\text { bellar atrophy }\end{array}$ & $\begin{array}{l}\text { EMG ( } 30 \text { months): } \\
\text { Absent sensory } \\
\text { responses } \\
\text { Auditory evoked } \\
\text { potentials (18 } \\
\text { months): Abnormal }\end{array}$ & $\begin{array}{l}\text { Compound heterozygous } \\
\text { c. } 1523 \mathrm{~A}>\mathrm{G}(\mathrm{p} . \\
\text { Tyr508Cys) and } \\
\text { c.952G }>\mathrm{A}(\mathrm{p} . \\
\text { Ala318Thr) } \\
\text { (sibling of case 5) }\end{array}$ & [4] \\
\hline 5 & 5 months & $\begin{array}{l}\text { Age } 4 \text { years at } \\
\text { time of report } \\
(2012)\end{array}$ & $\begin{array}{l}5 \text { months: Abnormal eye } \\
\text { movements. } \\
6 \text { months: Hypotonia, } \\
\text { poor visual fixation, ataxia } \\
\text { (suspected), areflexia, } \\
\text { athetosis } \\
11 \text { months: Dysphagia } \\
25 \text { months: Myoclonus } \\
\text { and epilepsia partialis } \\
\text { continua progressing to } \\
\text { refractory generalized } \\
\text { convulsive status epilepti- } \\
\text { cus } \\
4 \text { years: Ophthalmoparesis }\end{array}$ & $\begin{array}{l}11 \text { months: Feeding } \\
\text { intolerance, failure to } \\
\text { thrive. } \\
8.5 \text { months: } \\
\text { Hepatic dysfunction } \\
\text { (transaminitis). }\end{array}$ & 8.5 months: Normal & $\begin{array}{l}\text { EEG (8.5 months): Nor- } \\
\text { mal } \\
\text { EEG ( } 25 \text { months): Focal } \\
\text { irritation with general- } \\
\text { ization } \\
\text { EMG ( } 8.5 \text { months): } \\
\text { Absent sensory } \\
\text { responses }\end{array}$ & $\begin{array}{l}\text { Compound heterozygous } \\
\text { c. } 1523 \mathrm{~A}>\mathrm{G}(\mathrm{p} . \\
\text { Tyr508Cys) and } \\
\text { c. } 952 \mathrm{G}>\mathrm{A}(\mathrm{p} . \\
\text { Ala318Thr) } \\
\text { (sibling of case } 4)\end{array}$ & [4] \\
\hline 6 & Neonatal & 6 months & $\begin{array}{l}10 \text { weeks: Dysconjugate } \\
\text { gaze, seizures }\end{array}$ & $\begin{array}{l}\text { Neonatal: Hypoglycemia, } \\
\text { hyperammonemia. } \\
10 \text { weeks: Renal tubul- } \\
\text { opathy, hepatomegaly } \\
\text { and liver failure }\end{array}$ & $\begin{array}{l}4 \text { days/10 weeks (with } \\
\text { MRS): Both normal }\end{array}$ & $\begin{array}{l}\text { Visual and auditory } \\
\text { evoked potentials ( } 10 \\
\text { weeks): Abnormal }\end{array}$ & $\begin{array}{l}\text { Compound heterozygous } \\
\text { C85C }>\mathrm{T} \text { (p.Arg29Ter) } \\
\text { and c1523A }>\mathrm{G} \text { (p. } \\
\text { Tyr508Cys) }\end{array}$ & [5] \\
\hline 7 & Unknown & 3 months & $\begin{array}{l}\text { Limited information } \\
\text { available }\end{array}$ & $\begin{array}{l}\text { Limited information } \\
\text { available. } 3 \text { months: } \\
\text { Renal tubulopathy, lac- } \\
\text { tic acidosis. }\end{array}$ & $\mathrm{N} / \mathrm{A}$ & $\mathrm{N} / \mathrm{A}$ & $\begin{array}{l}\text { Homozygous c.1183T >C } \\
\text { (p.Phe395Leu) } \\
\text { (sibling of patient } 8 \\
\text { and 9) }\end{array}$ & [6] \\
\hline
\end{tabular}


Table (Continued)

\begin{tabular}{|c|c|c|c|c|c|c|c|c|}
\hline Case & Symptom Onset & Survival & Neurological Features & $\begin{array}{l}\text { Non-Neurological } \\
\text { Features }\end{array}$ & MRI Brain & Electrophysiology & Mutation(s) & Ref \\
\hline 8 & Neonatal & 4 months & 6 weeks: Irritability & $\begin{array}{l}\text { Neonatal: Jaundice, vom- } \\
\text { iting, feeding intoler- } \\
\text { ance, elevated lactate. } \\
6 \text { weeks: Hypoglyce- } \\
\text { mia, renal tubulopathy, } \\
\text { hepatic dysfunction } \\
\text { (mild transaminitis), } \\
\text { elevated tyrosine (uri- } \\
\text { nary succinylacetone } \\
\text { normal), lactic acidosis. }\end{array}$ & $\mathrm{N} / \mathrm{A}$ & $\mathrm{N} / \mathrm{A}$ & $\begin{array}{l}\text { Homozygous c.1183T >C } \\
\text { (p.Phe395Leu) } \\
\text { (sibling of patient } 7 \\
\text { and 9) }\end{array}$ & [6] \\
\hline 9 & Neonatal & 6 months & $\begin{array}{l}\text { 0-3 months: Irritability, } \\
\text { lethargy hypotonia, poor } \\
\text { suck/swallow, abnormal } \\
\text { visual behaviors }\end{array}$ & $\begin{array}{l}\text { Neonatal: Hypoglycemia, } \\
\text { hepatic dysfunction } \\
\text { (hepatomegaly, mild } \\
\text { transaminitis, conju- } \\
\text { gated hyperbilirubine- } \\
\text { mia) newborn screen } \\
\text { positive for tyrosine- } \\
\text { mia (urinary succinyla- } \\
\text { cetone negative), renal } \\
\text { tubulopathy, failure to } \\
\text { thrive, feeding } \\
\text { intolerance. }\end{array}$ & 3 months: Normal & $\begin{array}{l}\text { EEG ( } 3 \text { months): Dif- } \\
\text { fusely slow, poorly } \\
\text { organized background }\end{array}$ & $\begin{array}{l}\text { Homozygous c.1183T }>C \\
\text { (p.Phe395Leu) } \\
\text { (sibling of patient } 7 \\
\text { and 8) }\end{array}$ & [6] \\
\hline 10 & Neonatal & 21 months & $\begin{array}{l}5 \text { months: Hypotonia, psy- } \\
\text { chomotor regression } \\
7 \text { months: Abnormal eye } \\
\text { movements, lingual dyski- } \\
\text { nesias } \\
11 \text { months: Chorea (upper } \\
\text { limbs, face), areflexia } \\
12-21 \text { months: Loss of } \\
\text { visual fixation }\end{array}$ & $\begin{array}{l}\text { 0-5 months: Recurrent } \\
\text { vomiting } \\
7 \text { months: Failure to } \\
\text { thrive } \\
1 \text { year: Elevated AFP, } \\
\text { abnormal } \\
\text { glycosylation profile } \\
\text { suggestive of type I } \\
\text { CDG }\end{array}$ & $\begin{array}{l}1 \text { year (brain and spine): } \\
\text { Normal }\end{array}$ & $\begin{array}{l}\text { EEG (1 year): Poorly } \\
\text { organized background } \\
\text { Auditory evoked } \\
\text { potentials ( } 1 \text { year): } \\
\text { Bilateral sensorineural } \\
\text { hearing loss. } \\
\text { EMG ( } 1 \text { year): Sensori- } \\
\text { motor neuropathy. }\end{array}$ & $\begin{array}{l}\text { Compound heterozygous } \\
\text { c.316G }>\text { A (p.Lys106- } \\
\text { Glu) } \\
\text { and c.1181G }>\text { A (p. } \\
\text { Arg394His) }\end{array}$ & [7] \\
\hline 11 & Neonatal & 4 months & $\begin{array}{l}2 \text { months: Irritability, severe } \\
\text { hypotonia, psychomotor } \\
\text { delay, dysconjugate gaze, } \\
\text { poor visual fixation, lin- } \\
\text { gual dyskinesias, areflexia } \\
4 \text { months: Bilateral ptosis, } \\
\text { refractory status } \\
\text { epilepticus }\end{array}$ & $\begin{array}{l}\text { Neonatal: Hypoglycemia, } \\
\text { failure to thrive. } \\
\text { Hyponatremia } \\
2 \text { months: Renal tubul- } \\
\text { opathy, lactic acidosis, } \\
\text { hepatic dysfunction } \\
\text { (mild transaminitis). } \\
3 \text { months: laryngoma- } \\
\text { lacia, hypertension. } \\
4 \text { months: Refractory } \\
\text { lactic acidosis, liver } \\
\text { failure. }\end{array}$ & $\begin{array}{l}2 \text { months: Normal } \\
4 \text { months (with MRS): } \\
\text { Mild cerebral atrophy }\end{array}$ & $\begin{array}{l}\text { EEG ( } 2 \text { months): Bilateral } \\
\text { independent temporal } \\
\text { discharges. } \\
\text { EEG ( } 4 \text { months): Multi- } \\
\text { ple independent spike } \\
\text { foci } \\
\text { EMG ( } 2 \text { months): } \\
\text { Absent sensory } \\
\text { responses; mild myo- } \\
\text { pathic features } \\
\text { EMG ( } 4 \text { months): } \\
\text { Unchanged }\end{array}$ & $\begin{array}{l}\text { Compound heterozygous } \\
\text { c.853C }>\mathrm{T} \text { (p. } \\
\text { Arg285Ter) and c1592 } \\
+4 \mathrm{~A}>\mathrm{G}\end{array}$ & Our patient \\
\hline
\end{tabular}


now, ptosis has been reported in other mitochondrial disorders, but not Twinkle-associated MDS.

Common laboratory features include neonatal hypoglycemia and, later, lactic acidosis and cholestatic liver dysfunction, as seen in our patient. In one patient reported by Bouchereau et al., plasma and CSF lactate remained normal and the patient had an abnormal glycosylation profile suggestive of congenital disorder of glycosylation type I. ${ }^{8}$ Renal tubulopathy has been reported in four patients, including ours. ${ }^{6,7}$

In previously reported patients, MRI findings ranged from normal to cerebellar atrophy. In our patient, mild cortical atrophy was present by four months. Electromyography (EMG) findings were consistent, with sensory neuropathy in the majority of reported patients.

Muscle biopsy findings were described in the patients reported by Sarzi et al. and Hakonen et al. ${ }^{4,5}$ Pathology included lipid accumulation and either decreased cox staining or cox-negative fibers, also seen in our patient. Muscle pathology was normal at autopsy in the patient reported by Goh et al. and one by Prasad et al., both presenting with predominant hepatic and renal failure. ${ }^{6,7}$ Liver pathology has demonstrated micro- or macrovesicular steatosis and cirrhosis in most patients. Mitochondrial DNA depletion was demonstrated in the patient tissues reported by Sarzi et al. and Goh et al. ${ }^{4,6}$

Unfortunately, there is limited evidence for effectiveness of supplements that have been used in other mitochondrial disorders. However, mitochondrial transplantation has been demonstrated to rescue mitochondrial respiratory function in animal models of myocardial and liver ischemia, as well as in cells harboring the mitochondrial DNA mutation MERRF A8344G, and may present a therapeutic option in patients with mitochondrial diseases in future. ${ }^{9}$

\section{Conclusions}

The typical presentation of autosomal recessive MDS is characterized by early onset hepatoencephalopathy, failure to thrive, psychomotor delay and/or regression, epileptic encephalopathy, sensory axonal neuropathy, progressive liver dysfunction, and in some patients, renal tubulopathy, movement disorders, and ophthalmoplegia. As such, MDS should be considered on the differential of early onset encephalopathy and multisystem failure. The description of this patient and the documentation of new mutations in the Twinkle gene is an important contribution to the understanding of this complex and severe neurodegenerative condition.

We thank the family for allowing us to present this case. Diane Love provided valuable input on the final draft of the manuscript.

\section{References}

1. Copeland WC. Defects of mitochondrial DNA replication. J Child Neurol. 2014;29:1216-1224.

2. Morino H, Pierce SB, Matsuda Y, et al. Mutations in Twinkle primase-helicase cause Perrault syndrome with neurologic features. Neurology. 2014;83:2054-2061.

3. Pierce SB, Gulsuner S, Stapleton GA, et al. Infantile onset spinocerebellar ataxia caused by compound heterozygosity for Twinkle mutations and modeling of Twinkle mutations causing recessive disease. Cold Spring Harbor Mol Case Stud. 2016;2:a001107.

4. Sarzi E, Goffart S, Serre V, et al. Twinkle helicase (PEO1) gene mutation causes mitochondrial DNA depletion. Ann Neurol. 2007;62:579-587.

5. Hakonen AH, Isohanni P, Paetau A, Herva R, Suomalainen A, Lonnqvist T. Recessive Twinkle mutations in early onset encephalopathy with mtDNA depletion. Brain. 2007;130:3032-3040.

6. Goh V, Helbling D, Biank V, Jarzembowski J, Dimmock D. Nextgeneration sequencing facilitates the diagnosis in a child with Twinkle mutations causing cholestatic liver failure. J Pediatr Gastroenterol Nutr. 2012;54:291-294.

7. Prasad C, Melancon SB, Rupar CA, et al. Exome sequencing reveals a homozygous mutation in TWINKLE as the cause of multisystemic failure including renal tubulopathy in three siblings. Mol Genet Metab. 2013;108:190-194.

8. Bouchereau J, Barrot SV, Dupre T, et al. Abnormal glycosylation profile and high alpha-fetoprotein in a patient with Twinkle variants. JIMD Rep. 2016;29:109-113.

9. McCully JD, Levitsky S, del Nido PJ, Cowan DB. Mitochondrial transplantation for therapeutic use. Clin Trans Med. 2016;5:16. 